\title{
JALUR KERETA API PELABUHAN CIREBON: \\ JEJAK ANGKUTAN KOMODITAS PERDAGANGAN PADA MASA \\ KOLONIAL BELANDA 1897-1942
}

The Railroad to Cirebon Port: Traces of Transport of Commodities in Trade in the

Dutch Colonial Period (1897-1942)

\author{
Iwan Hermawan \\ Balai Arkeologi Jawa Barat \\ Jalan Raya Cinunuk Km. 17 Cileunyi Bandung, Indonesia \\ E-mail: iwan.hermawan@kemdikbud.go.id
}

Naskah diterima: 02-07-2020; direvisi: 02-12-2020; disetujui: 23-03-2021

\begin{abstract}
The high demand for various plantation commodities in the world market, especially sugar, encourages the construction and operation of railroad lines in the Cirebon region. The construction and operation of railroad lines in Cirebon are directed to facilitate commodity traffic to be sent through the Port of Cirebon. The problem raised in this paper is related to what archeological remains are markers of the existence of the Cirebon-Cirebon Port Railway. The method used to answer these problems is the descriptive analysis method. Data collection was carried out through literature study and field observations. Dutch colonial railroad relics on the track in the form of the railbed, signal pole structure, boundary stakes, bridge structure, level crossing pole structure, and rail rods that are still installed. The existence of the railroad remains is a proof of the activities of the train transportation mode to the Port of Cirebon.
\end{abstract}

Keywords: railroad, trade traffic, SCS

\begin{abstract}
Abstrak
Tingginya permintaan berbagai komoditas perkebunan di pasaran dunia, terutama gula mendorong dibangun dan dioperasikannya jalur kereta api di wilayah Cirebon. Pembangunan dan pengoperasian jalur kereta api di Cirebon diarahkan untuk memperlancar lalu lintas komoditas yang akan dikirim melalui Pelabuhan Cirebon. Salah satu bagian dari jalur kereta api yang dibangun, adalah jalur Stasiun cirebon - Pelabuhan Cirebon. Permasalahan yang diangkat pada tulisan ini, adalah berkenaan dengan tinggalan arkeologi apa saja yang menjadi penanda keberadaan Jalur kereta api Cirebon - Pelabuhan Cirebon. Metode yang dipergunakan untuk menjawab permasalahan tersebut, adalah Metode deskriptif analisis. Pengumpulan data dilakukan melalui studi Pustaka, dan pengamatan lapangan. Saat ini, Jalur kereta Cirebon Pelabuhan merupakan jalur tidak aktif di wilayah Cirebon. Tinggalan perkeretaapian masa Kolonial belanda di jalur tersebut berupa railbed, struktur tiang sinyal, patok batas, patok KM, struktur jembatan, struktur tiang perlintasan sebidang, dan batang rel yang masih terpasang. Keberadaan tinggalan perkeretaapian tersebut merupakan bukti aktifitas moda angkutan kereta api menuju Pelabuhan Cirebon.

Kata kunci: jalur kereta api, lalu lintas perdagangan, SCS
\end{abstract}




\section{PENDAHULUAN}

Cirebon merupakan salah satu kota pelabuhan di Pesisir Utara Pulau Jawa, keberadaanya sebagai kota dagang sudah berlangsung jauh sebelum bangsa Eropa datang ke Nusantara. Pada awal abad ke-16, Cirebon sudah dikenal sebagai kota perdagangan terutama untuk komoditas beras dan hasil bumi yang diekspor ke Malaka (Lubis 2000, 33). Keberadaan Cirebon sebagai kota pelabuhan semakin kuat ketika diberlakukannya Politik Tanam Paksa yang berlangsung pada tahun 1830-1870. Berbagai komoditas pertanian, perkebunan, dan kehutanan dikirim melalui Pelabuhan Cirebon ke berbagai wilayah di Nusantara dan berbagai belahan dunia lainnya. Kondisi ini berlanjut pada masa ekonomi liberal pasca ditetapkannya Undang-Undang Agraria tahun 1870, yang mendorong berkembangnya perkebunan milik pengusaha swasta. Meningkatnya hasil pertanian dan perkebunan, serta lakunya komoditas tersebut di pasaran dunia, tidak diimbangi dengan pengangkutan yang memadai, sehingga banyak komoditas ekspor yang rusak atau busuk di gudanggudang penampungan. Hal ini disebabkan oleh waktu tempuh yang panjang dari pusat-pusat komoditas ke pelabuhan, serta jumlah barang yang dapat diangkut oleh gerobak sangat sedikit volumenya (Hendro 2014, 24).

Guna mempercepat aliran barang dari gudang-gudang penampung ke pelabuhan, maka dibangunlah moda transportasi massal yang mampu mengangkut barang dalam jumlah besar, serta tepat waktu sampai tujuan yaitu Kereta Api (Cahyo 2017, 1410). Pemilihan dikembangkannya angkutan kereta api karena berdasarkan pengalaman di Eropa, keberadaannya mampu mengatasi permasalahan pengangkutan barang secara massal. Keberadaan sarana transportasi tersebut dapat mendukung keberhasilan politik Tanam Paksa, yang diberlakukan Belanda di Pulau Jawa pada abad ke-19, yang kemudian berlanjut dengan berkembangnya ekonomi liberal. Kehadiran moda transportasi kereta api, jelas memberikan pengaruh yang sangat besar di bidang ekonomi, terutama dalam pengangkutan komoditas ekspor dari pedalaman ke Pelabuhan (Darini et al. 2014, 14-15). Pembangunan perkeretaapian tidak hanya ditujukan untuk kepentingan ekonomi semata, namun juga untuk tujuan pertahanan, seperti pembangunan kereta api di Aceh atau Atjehtram (Usman dan Rachmatsyah 2017, 588).

Pembangunan dan pengoperasian Kereta Api di Jalur Pantai utara Jawa, antara SemarangCirebon, dilakukan oleh Perusahaan Kereta Api Swasta NV Java Spoorweg Maatschappij (JSM), bagian dari Perusahaan Kereta Api Batavia Ooster Spoorweg Maatschappij (BOS) - Perusahaan KA Batavia Timur (Marihandono et al. 2016, 29). JSM memperoleh konsesi pembangunan dan pengoperasian Jalur Tegal - Balapulang sepanjang 25 tahun 1882, dan resmi beroperasi pada 17 November 1886 (Tim Telaga Bakti Nusantara 1997, 70). Berbeda dengan perusahaan kereta api lainnya yang memperoleh keuntungan dari pengoperasian jalur kereta api, JSM mengalami kerugian ketika mengoperasikan jalur Tegal - Balapulang. Besaran kerugian yang dialami JSM diuraikan pada tabel 1.

Tabel 1. Pendapatan dan Biaya Eksploitasi JSM di Jalur Tegal - Balapulang

\begin{tabular}{llll}
\hline Keterangan & Tahun 1887 & Tahun 1888 & Tahun 1889 \\
\hline Penerimaan Bruto & F 29.881,98 & F 39.791,00 & F 42.778,98 \\
Biaya Eksploitasi & F 60. 116,11 & F 50.770,65 & F 49.546,00 \\
Saldo rugi & F 30.234,12 & F 10.979,65 & F 6.757,81 \\
\hline
\end{tabular}

(Sumber: Marihandono et al. 2016, 44) 
Tabel 1 menunjukkan, tingginya biaya eksploitasi yang dikeluarkan JSM tidak sebanding dengan pendapatan yang diperoleh. Walau angka kerugian dari tahun ke tahun terlihat menurun, namun keberadaan saldo rugi akan mengurangi jumlah modal yang tersedia. Kondisi ini terjadi akibat tarif yang diterapkan pada jalur tersebut tidak terjangkau oleh masyarakat sehingga jumlah penumpang terus menurun. Hal inilah yang mendorong Direksi JSM memutuskan untuk menjual perusahaan tersebut. Kesepakatan pengambilalihan Perusahaan JSM dilakukan tanggal 18 Januari 1892, dengan NV Semarang - Cheribon Stoomtram-Maatschappij (SCS) selaku pembeli. Sejak saat itu konsesi jalur Pantai Utara Jawa antara Semarang sampai Cirebon dikuasai oleh SCS. Pada tanggal 16 September 1895, jalur kereta api Tegal-Slawi-Balapulang untuk pertama kalinya dibuka bagi lalu lintas sebagai jalur trem oleh SCS (Marihandono 2016, 18-19).

Sesuai dengan namanya, SCS membangun dan mengoperasikan lintas trem atau kereta api ringan yang menghubungkan Kota Semarang, dengan Kota Cirebon melalui beberapa jalur percabangan. Lintas tersebut melewati kotakota di Pantai Utara Jawa seperti Pekalongan dan Tegal. Jaringan SCS disebut juga suikerlijn atau jalur gula karena melayani 27 pabrik gula yang berada di sepanjang jaringannya pada 1905 (Raap 2017, 241). SCS memperoleh konsesi selama 99 tahun terhitung sejak tanggal 4 Mei 1895 hingga 5 April 1994 (Marihandono 2016, 19). Tujuan utama konsesi ini adalah membuka dan mengeksploitasi jalur trem uap Cirebon-Semarang, dan membeli jalan kereta api sekunder Tegal-Balapulang yang akan dieksploitasi sebagai jalan trem. Namun, izin dari pemerintah kepada SCS untuk melakukan eksploitasi jalur trem Cirebon-Semarang baru diberikan pada tanggal 21 Desember 1895. Pada tahun 1897-1899 secara bertahap SCS membangun dan mengoperasikan jalur kereta api yang menghubungkan Semarang dengan
Cirebon. Ruas terakhir dari Jalur SemarangCirebon diselesaikan dan dioperasikan pada tanggal 1 Februari 1899 (Subarkah 1992, 31). Ruas terakhir yang dioperasikan SCS adalah jalur menuju Pelabuhan dari Stasiun Cirebon SCS atau Cirebon Prujakan, walau secara resmi jalur Semarang-Cirebon sudah tersambung dan resmi beroperasi sejak tahun 1897. Pengajuan izin pemasangan rel di lingkungan Pelabuhan Cirebon dan Semarang oleh direksi SCS dilakukan pada tahun 1896 dan izin serupa juga dimintakan untuk Pelabuhan Pekalongan pada tahun 1897. Izin tersebut baru diterbitkan pemerintah tahun 1899, melalui Besuit van Gouverneur Generaal No. 53 tahun 1899. Salah satu ketentuannya, adalah "Bila dalam persyaratan ini disebutkan tentang jalan trem Semarang-Cirebon, juga di dalamnya termasuk cabang ke berbagai pelabuhan yang terletak di sepanjang jalur-jalur ini, yang dalam keputusan khusus izin diberikan oleh Gubernur Jenderal untuk membuka dan mengeksploitasinya" (Marihandono et al. 2016, 91). Pada tahun 1899, Gubernur Jenderal Hindia Belanda pada masa itu, adalah Jhr. Carel Herman Aart van der Wijk (17 Oktober 1893-3 Oktober 1899) ("Regeerings-Almanak Voor NederlandschIndie 1930. Eerste Gededeelte.” 1930, 871-72).

Perusahaan kereta api lainnya yang beroperasi di Cirebon adalah perusahaan kereta api pemerintah, Staatsspoorwagen (SS). SS membangun jalur kereta api Cikampek-Cirebon sebagai kelanjutan dari jalur Batavia-Cikampek (Hermawan dan Mainaki 2019, 565). Jalur ini tersambung pada tahun 1912 dan membangun stasiun utama di Kejaksan, berjarak $1 \mathrm{~km}$ dari Stasiun Cirebon SCS di Prujakan. SS membangun Stasiun Cirebon SS di kejaksan dengan bangunan megah dan memiliki kesan monumental pada masanya (Wardhani 2014, 145).

Penerbitan izin dari Gubernur Jenderal untuk pembukaan dan eksploitasi jalur kereta api dari Stasiun Cirebon ke Pelabuhan Cirebon mendorong jajaran direksi SCS segera 
memulai pembangunan rel trem ke pelabuhan. Pembangunan rel dilakukan dengan cara membangun jaringan trem dari Stasiun Cirebon ke komplek Pelabuhan Cirebon. Jalur tersebut bersinggungan dengan jalur SS dan belum ada kepastian izin penggunaan rel bersama dari SS. Sebelum terbitnya izin penggunaan rel bersama, SCS memutuskan untuk melakukan pemasangan rel yang bersifat sementara sampai terbitnya keputusan pemerintah berkenaan dengan hal tersebut. Keputusan pemerintah akhirnya terbit dan salah satu isinya menyebutkan bahwa SS tidak akan membangun rel untuk kepentingan pengangkutan produk ke Pelabuhan Cirebon. Pemerintah menghendaki SCS bisa melakukan kesepakatan dengan SS tentang pemanfaatan rel secara bersama. Karena rel yang dipasang untuk trem, sedangkan SS mengoperasikan kereta api, maka kesepakan yang dijalin antara SCS dan SS adalah kontrak pengalihan angkutan komoditi SS ke gerbong-gerbong SCS untuk seterusnya dibawa ke Pelabuhan (Marihandono et al. 2016, 92). Pemindahan barang-barang tersebut dari gerbong SS ke gerbong SCS dilakukan di Stasiun Cirebon SS, demikian pula sebaliknya barang-barang yang diangkut gerbong SCS dari pelabuhan dengan tujuan daerah-daerah yang dilayani SS akan dialihkan ke gerbong barang SS. Hal ini diuraikan oleh Residen Cirebon, C. J. A. E. T. Hiljee, pada memori serah jabatan tanggal 3 Juni 1930 (Arsip Nasional Republik Indonesia 1976, CL-CLIV).

Saat ini, jalur kereta api CirebonPelabuhan Cirebon sepanjang $2 \mathrm{~km}$ merupakan salah satu jalur kereta api non-aktif di wilayah kerja PT. Kereta Api Indonesia DAOP 3 Cirebon. Kondisinya sudah beralih fungsi menjadi tapak rumah warga, dan jalan warga (gang). Jalur kereta api tersebut saat ini terbentang di sepanjang Gang Sudarma, Gang Buntu, Pamitran, Jalan Syech Magelung, dan kawasan Pelabuhan Cirebon.

Permasalahan yang diangkat pada tulisan ini, adalah tinggalan arkeologi apa saja yang menjadi penanda atau bukti keberadaan jalur kereta api Cirebon-Pelabuhan Cirebon. Tujuan dari tulisan ini adalah mendeskripsikan tinggalan arkeologi masa kolonial berupa jejak perkeretaapian di sepanjang Jalur kereta api Cirebon-Pelabuhan Cirebon.

\section{METODE}

Penelitian ini dilaksanakan di Kota Cirebon, tepatnya di jalur kereta api non-aktif Cirebon-Pelabuhan. Jalur ini membentang dari Stasiun Cirebon (Kejaksan) dan Stasiun Cirebon Prujakan yang merupakan dua stasiun besar di Kota Cirebon sampai ke Pelabuhan Cirebon sepanjang $2 \mathrm{~km}$. Jalur ini merupakan jalur perkeretaapian yang berada di wilayah operasional PT. Kereta Api Indonesia (KAI) Daerah Operasional (DAOP) 3 Cirebon. Secara administratif jalur kereta api ini berada di Kecamatan Kejaksan, Pekalipan, dan Lemahwungkuk Kota Cirebon, Provinsi Jawa Barat.

Penelitian ini merupakan penelitian eksploratif deskriptif, dengan mengikuti pola penalaran induktif. Data yang dikumpulkan pada penelitian ini terbatas pada tinggalan arkeologi perkeretaapian, peta, dan arsip masa Kolonial Belanda (Reiter 2017, 142-45). Data yang diperoleh dideskripsi, selanjutnya dianalisis dengan menggunakan pendekatan keruangan yang mencakup prinsip penyebaran, serta interelasi dalam ruang dan antar ruang (Sumaatmadja 1988, 77-86). Pendekatan keruangan digunakan guna mengetahui keterkaitan atau interaksi antar ruang dan di dalam ruang, yaitu jalur kereta api dari Stasiun Cirebon (Kejaksan) dan Stasiun Cirebon Prujakan ke Pelabuhan Cirebon.

Pengumpulan data awal dilakukan melalui kegiatan studi pustaka, termasuk studi terhadap peta tata ruang Kota Cirebon pada masa kolonial Belanda, dan studi arsip yang meliputi arsip perkeretaapian dan arsip lainnya yang terkait dengan pembangunan dan pengoperasian kereta api di Cirebon. Hal ini dilakukan guna mengetahui sejarah perkeretaapian di 
Indonesia, khususnya di wilayah Cirebon dan perkembangan pembangunan Kota Cirebon pada masa kolonial Belanda.

Pengumpulan data lapangan dilakukan dengan cara pengamatan terhadap tinggalan perkeretaapian di lokasi penelitian yang dilaksanakan di Bulan April-Mei 2019. Jalur kereta api Stasiun Cirebon-Pelabuhan saat ini berstatus sebagai jalur kereta api nonaktif (jalur mati), dan sudah beralih fungsi menjadi kawasan pemukiman padat penduduk. Pengamatan lapangan dilakukan dengan mengikuti bekas railbed (landasan dimana rel dipasang atau tempat dipasangnya rel kereta api), yang membentang dari Stasiun Cirebon dan Stasiun Cirebon Prujakan sampai Pelabuhan. Pengamatan lapangan tersebut dilakukan, untuk memperoleh data tinggalan arkeologis berupa fasilitas perkeretaapian di sepanjang jalur kereta api Stasiun Cirebon-Pelabuhan. Tulisan ini juga mempergunakan data hasil penelitian arkeologi tentang perkeretaapian di wilayah Cirebon dan sekitarnya, yang dilakukan Balai Arkeologi Jawa Barat tahun 2017 dan 2018.

Data yang berhasil dikumpulkan tersebut selanjutnya dilakukan analisis dengan pendekatan keruangan guna mengetahui hubungan antar-ruang dan di dalam ruang lokasi penelitian untuk selanjutnya dideskripsikan dan diinterpretasi guna menjawab permasalahan yang diajukan.

\section{HASIL DAN PEMBAHASAN}

Jalur kereta api Cirebon-Pelabuhan merupakan salah satu jalur non-aktif di wilayah kerja PT. KAI DAOP 3 Cirebon. Jalur sepanjang kurang dari $2 \mathrm{~km}$ ini dibangun SCS untuk memfasilitasi pengangkutan barang dari stasiun akhir Cirebon (Kejaksan dan Prujakan) ke Pelabuhan Cirebon. Barang-barang yang diangkut kereta api langsung dikirim ke gudanggudang di Pelabuhan Cirebon. Pada gambar 1 tampak jalur tersebut berawal di Stasiun Cirebon Prujakan dan Stasiun Cirebon Kejaksan serta berakhir di lingkungan Pelabuhan Cirebon. Penutupan jalur tersebut tidak terlepas dari kalahnya angkutan barang kereta api oleh angkutan darat lainnya, yaitu truk yang dapat mengangkut barang dalam jumlah yang lebih sedikit dan mampu menjangkau tujuan akhir barang tersebut. Seiring dengan berjalannya waktu, jalur kereta api Cirebon-Pelabuhan secara kasat mata sudah sulit dikenali karena lahannya sudah beralih fungsi menjadi kawasan permukiman. Keberadaan jalur tersebut dapat dikenali melalui tinggalan perkeretaapian yang masih tersisa di sepanjang jalur kereta api antara Stasiun Cirebon dengan Pelabuhan Cirebon. Pada bagian ini, deskripsi tinggalan arkeologi dikelompokkan menjadi tiga, yaitu Stasiun Cirebon-Jalan Siliwangi, Jalan Siliwangi-Jembatan Kalibaru, dan Lingkungan Pelabuhan.

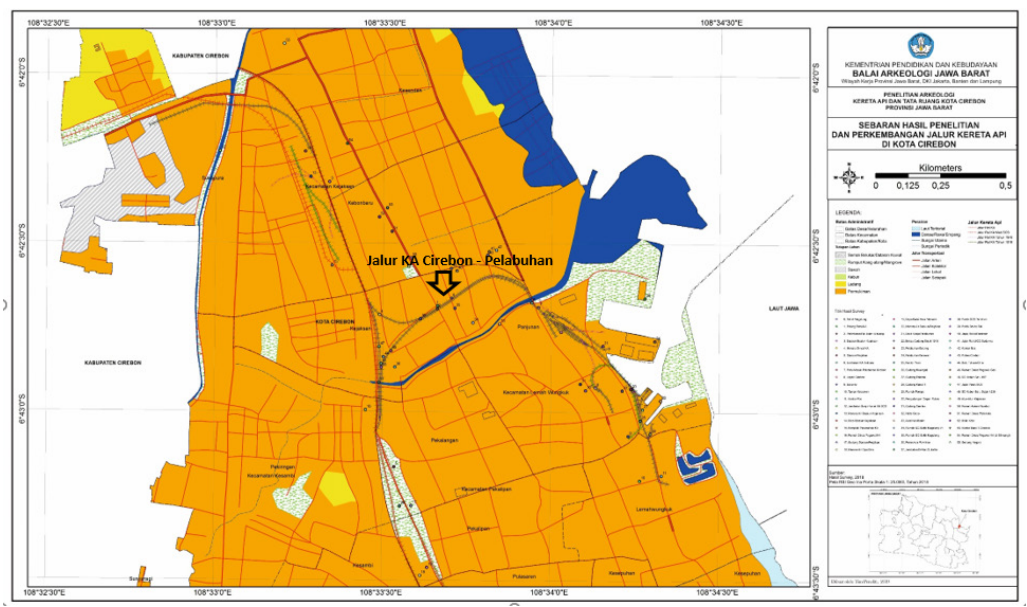

Gambar 1. Peta sebaran tinggalan Perkeretaapian di Cirebon. Jalur Kereta Api Cirebon-Pelabuhan yang menjadi lokasi penelitian ditunjukkan dengan tanda panah.

(Sumber: Dokumentasi Balar Jawa Barat, 2019) 


\section{Stasiun Cirebon-Jalan Siliwangi}

Pada bagian terdahulu sudah diuraikan bahwa jalur kereta api ini membentang dari Stasiun Cirebon Prujakan dan Stasiun Cirebon Kejaksan sampai lingkungan Pelabuhan Cirebon. Jalur kereta api dari Stasiun Cirebon Prujakan dan Stasiun Cirebon Kejaksan ke Pelabuhan membentuk segitiga, karena kedua stasiun tersebut memiliki cabang ke pelabuhan masing-masing dan jalur tersebut menyatu di kawasan Syekh Magelung (gambar 1). Saat ini, jalur percabangan dari Stasiun Cirebon Kejaksan telah beralih fungsi menjadi jalan warga, yaitu Gang Buntu. Jalur percabangan dari stasiun Cirebon Prujakan juga beralih fungsi menjadi alas perumahan warga di sepanjang Gang Sudarma.

Gang Buntu adalah nama jalan (gang) yang berada di dekat Perlintasan sebidang Jalan RA. Kartini. Jalan (gang) ini menghubungkan Jalan Kartini dengan Jalan KS. Tubun Kota Cirebon. Sebelum difungsikan sebagai jalan (gang), Gang Buntu merupakan railbed jalan rel kereta api dari Stasiun Cirebon Kejaksan ke Pelabuhan. Percabangan ke Pelabuhan dari stasiun Cirebon Kejaksan berada di Sepur 1. Setelah melewati perlintasan kereta api di Jalan Kartini, jalan rel berbelok ke arah timur dan menyebrang Jalan KS. Tubun (gambar 2).

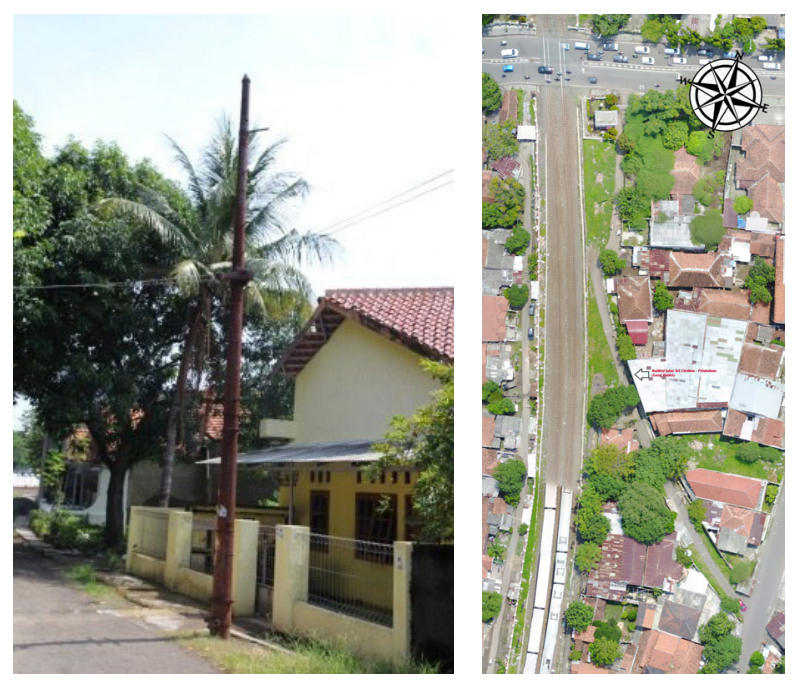

Gambar 2. Railbed Jalur KA Cirebon Pelabuhan: (kiri) Tiang Sinyal Mekanik di Gang Buntu; (kanan) Foto udara Gang Buntu.

(Sumber: Dokumentasi Balar Jawa Barat, 2019)
Gang Sudarma yang terletak di RT 01 RW 03 Kelurahan Pamitran, merupakan jalan yang menghubungkan permukiman warga dengan Jalan KS Tubun dengan mulut gang menghadap Timur. Railbed jalur kereta api dari Stasiun Prujakan ke Pelabuhan di kawasan ini sejajar Gang Sudarma, posisinya sisi Utara Jalan Gang dan sudah tidak terlihat, karena di atasnya berdiri bangunan permukiman warga yang berjajar dari Kali Sukalila sampai Jalan KS. Tubun, dan membentuk rumah deret yang bentuknya mengikuti jalur kereta api. Deretan bangunan permanen dan semi permanen di sisi timur Gang Sudarma berdiri di atas Railbed Jalur Kereta Api Prujakan-Pelabuhan. Kondisi ini dibuktikan dengan terdapatnya singkapan rel kereta api di beberapa titik di halaman rumah warga, menempel di pondasi rumah. Pada gambar 3 terlihat rel kereta api yang masih

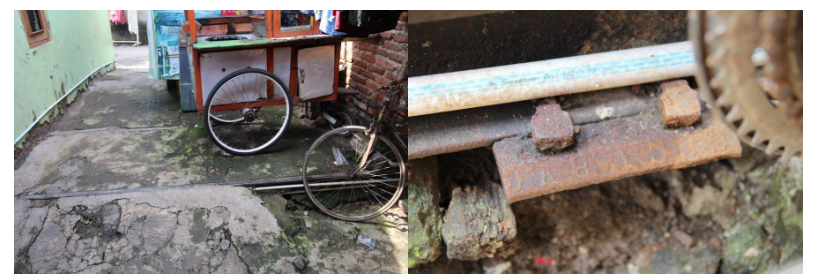

Gambar 3. Jejak Rel yang tersingkap di Gg. Sudarma. (Sumber: Dokumentasi Balar Jawa Barat, 2019)

terpasang dengan pasak rel lengkap dengan plat penguncinya dan berterakan SCS BVC, teraan tersebut menunjukkan bahwa rel tersebut merupakan rel produksi BVC BOCHUM untuk perusahaan kereta api SCS. Pada saat kereta api mulai beroperasi di Nusantara, semua kebutuhan untuk pembangunan jalur kereta api didatangkan dari Eropa. Perusahaan besar seperti KRUPP, BVC BOCHUM, dan perusahaan lainnya merupakan perusahaanperusahaan pemasok rel dan prasarana perkeretaapian lainnya pada masa itu.

\section{Tiang Sinyal Mekanik}

Jejak perkeretaapian di Gang Buntu, adalah jalur jalan rel (Railbed) yang sekarang difungsikan sebagai jalan oleh warga, dan tiang sinyal mekanik yang terletak di koordinat $108^{\circ}$ 33' 28,962" E; 6 42' 42,826" S (gambar 2). 
Tiang tersebut berupa tiang besi dengan bekas dudukan sinyal di bagian atasnya. Pada saat jalur kereta api ini masih aktif, tiang sinyal mekanik dipasang menjelang Stasiun Cirebon yang berfungsi sebagai pengatur lalu lintas kereta api keluar dan masuk lingkungan stasiun dari atau ke arah pelabuhan.

\section{Jembatan Sukalila}

Jembatan Sukalila merupakan jembatan kereta api yang terletak di Jalur Kereta Api Cirebon Prujakan (CNP) ke Pelabuhan. Jembatan ini berada tidak jauh dari Stasiun Cirebon Prujakan (CNP), pada koordinat $6^{\circ} 42^{\prime}$ 54,760" LS; $108^{\circ} 33$ ' 29,004" BT, berdampingan dengan jembatan kereta api pada jalur aktif petak stasiun Cirebon PrujakanStasiun Cirebon. Saat ini, kondisi badan jembatan sudah hancur dan tersisa salah satu balok besi jembatan yang melintang Kali Sukalila. Dari struktur jembatan yang masih tersisa, jembatan tersebut merupakan jembatan rusuk dengan tanpa tiang penyangga jembatan di tengah. Penyangga jembatan berupa Abutmen di tiap sisi jembatan (gambar 4).

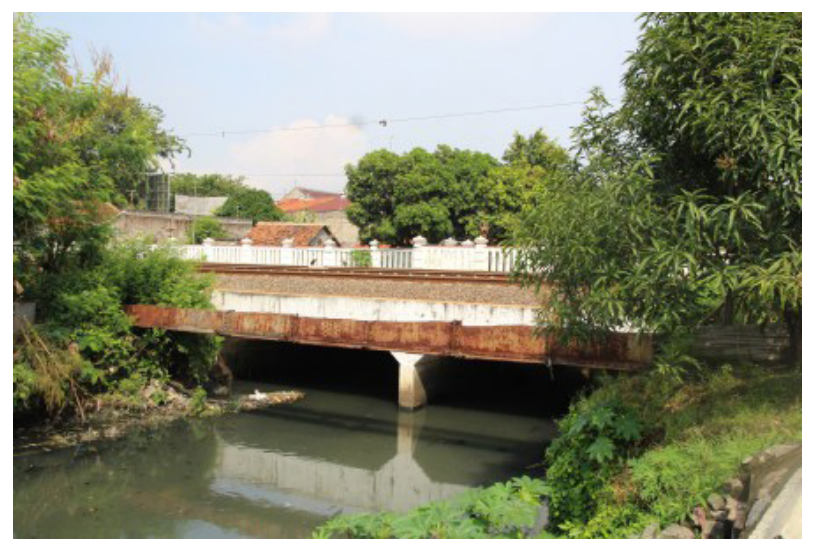

Gambar 4. Struktur Jembatan Sukalila. Jembatan ini sejajar dengan Jembatan Kereta Api Aktif antara Stasiun Cirebon Prujakan dengan Stasiun Cirebon (Kejaksan).

(Sumber: Dokumentasi Balar Jawa Barat, 2019)

\section{Patok SCS}

Tinggalan fasilitas perkeretaapian lainnya, adalah patok batas (penanda batas lahan/aset). Patok ini berupa patok cor, berbentuk segi panjang dengan permukaan atas miring. Pada bagian atas patok terdapat teraan SCS, yang menunjukkan bahwa patok tersebut merupakan batas lahan konsesi SCS. Pada jalur kereta api Cirebon-Pelabuhan antara jalur aktif Stasiun Cirebon-Cirebon Prujakan sampai Perlintasan sebidang di Jalan Siliwangi, ditemukan 2 (dua) patok dengan teraan SCS, yaitu (1) di dekat jalur aktif di antara Gang Buntu-Jembatan Sukalila dan (2) di depan rumah Bapak Iwan Darmawan di Kelurahan Pamitran RT 003 RW 004 Kecamatan Kejaksan (gambar 5).

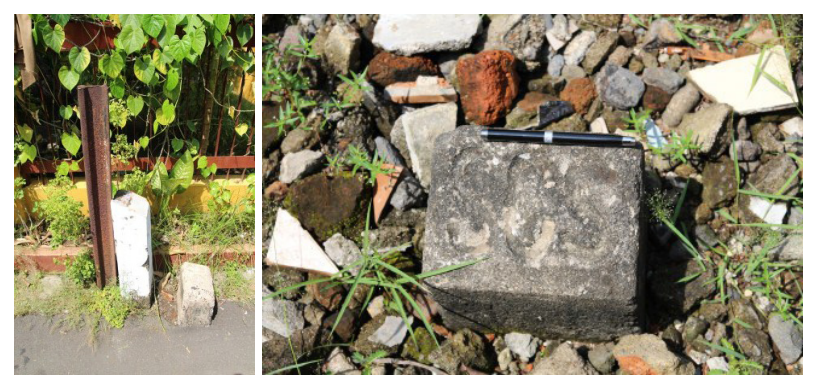

Gambar 5. Patok SCS: (kiri) Patok SCS di dekat Jalur aktif antara Stasiun Cirebon Prujakan dan Stasiun

Cirebon (Kejaksan), (kanan) Patok SCS di depan rumah Bapak Iwan Darmawan di Pamitran RT 03 RW 04. (Sumber: Dokumentasi Balar Jawa Barat, 2019)

\section{Jalan Siliwangi-Jembatan Kalibaru}

Jalur kereta api Cirebon - Pelabuhan, dari Pamitran menyebrang jalan raya (sekarang Jalan Siliwangi) menyusuri kawasan Jalan Syekh Magelung sampai di Jembatan Kalibaru (Kalianyar) sebelum berakhir di kawasa Pelabuhan Cirebon. Tinggalan perkeretaapian di petak ini, adalah struktur tiang pintu perlintasan, railbed, patok KM, dan Jembatan Kalibaru (Kalianyar).

\section{Perlintasan Jalan Siliwangi}

Jalan Siliwangi merupakan salah satu jalan utama dan sibuk di kota Cirebon sejak masa Hindia Belanda, karena kawasan tersebut merupakan pusat perekonomian. Jalan Siliwangi dilintasi oleh Jalur Kereta Api Cirebon - Pelabuhan. Agar perjalanan kereta api tidak terganggu saat melintas Jalan Siliwangi, maka di titik perlintasan sebidang tersebut dibangun pintu perlintasan (PJL). Seiring dengan dinonaktifkannya jalur Cirebon 
- Pelabuhan, maka perlintasan ini juga dihapus. Tinggalan yang tersisa saat ini adalah struktur tiang penopang pintu lintasan kereta api. Lokasinya tepat di ujung Jalan Syekh Magelung (gambar 6).

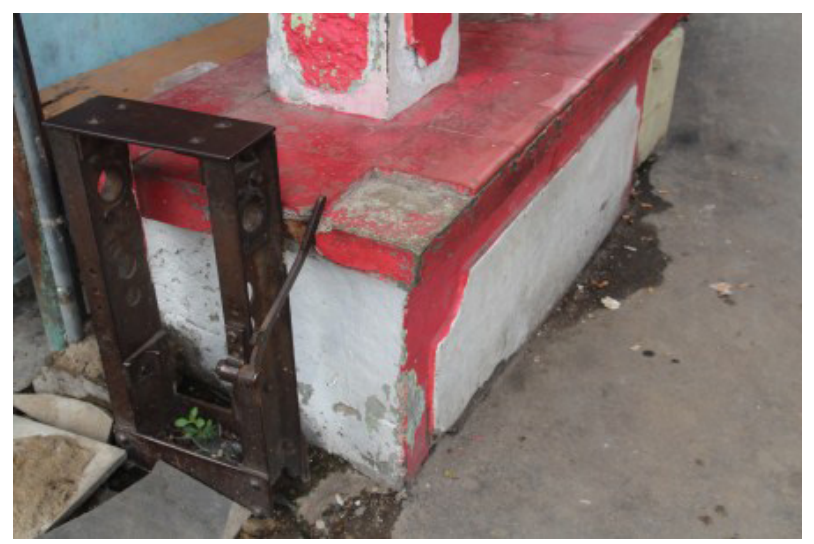

Gambar 6. Struktur Salah satu Tiang Pintu perlintasan Jl. Siliwangi.

(Sumber: Dokumentasi Balar Jawa Barat, 2019)

\section{Jalan Syekh Magelung}

Jalan Syekh Magelung merupakan jalan yang menghubungkan Jalan Siliwangi dengan Jalan Veteran. Jalan ini merupakan railbed jalur kereta api Cirebon - Pelabuhan. Berdasarkan Grondkaart PT. KAI dan Peta Kota Cirebon tahun 1918 dan 1946, Jalur kereta api menuju pelabuhan masih dua jalur, yaitu dari Stasiun Cirebon (Kajaksan) dan jalur dari Cirebon Prujakan. Jalur ini membentuk segitiga, yaitu railbed yang sekarang menjadi Gang Buntu (dari arah Stasiun Cirebon/CN) dan railbed yang menjadi Gang Sudarma (dari arah Stasiun Cirebon Prujakan/CNP). Kedua jalur rel tersebut merapat jaraknya di Pamitran, tepatnya di sekitar patok SCS di depan Rumah Bapak Iwan Darmawan di Kelurahan Pamitran RT 03 RW 04 , dan selanjutnya jalan rel sejajar menuju ke Utara melewati perlintasan sebidang Jalan Siliwangi, memasuki Jalan Syekh Magelung, dan bersatu sebelum Jembatan Kalibaru. Tinggalan perkeretaapian di Jalan Syekh Magelung, adalah railbed dan patok KM.

Railbed atau jalur kereta api Cirebon Pelabuhan, membentang dari Stasiun Cirebon dan Stasiun Cirebon Prujakan, sampai Stasiun Cirebon Pelabuhan saat ini sudah tidak

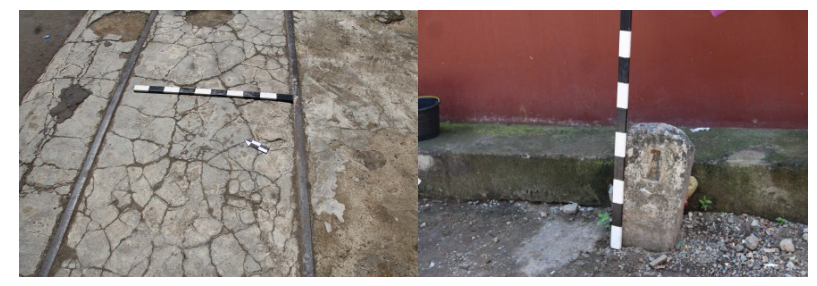

Gambar 7. (kiri) Jejak Rel dan (kanan) Patok KM di Jalan Syekh Magelung.

(Sumber: Dokumentasi Balar Jawa Barat, 2019)

difungsikan sebagai badan jalan rel kereta api, tetapi sebagian besar difungsikan sebagai jalan oleh masyarakat. Pada beberapa titik di Jalan Syekh Magelung, terdapat singkapan rel kereta api (gambar 7).

Patok KM (kilometer) atau penunjuk jarak, tinggalan perkeretaapian lainnya di kawasan Jalan Syekh Magelung, adalah struktur Patok KM. Patok KM merupakan penanda atau penunjuk jarak atau panjang jalan rel kereta api dari stasiun awal sampai titik tersebut. Patok KM dimaksud berupa struktur tiang Cor beton berbentuk pipih dengan tinggi $50 \mathrm{~cm}$ dan lebar $30 \mathrm{~cm}$ dengan bagian atas melingkar. Kondisi patok sudah rusak, namun masih terbaca pahatan angka pada patok tersebut, yaitu angka 1 (satu) (lihat gambar 7). Angka 1 tersebut menunjukkan jarak dari stasiun awal (Stasiun Cirebon) sampai titik tersebut adalah $1 \mathrm{KM}$. Lokasinya berada di Jalan Syekh Magelung di pinggir rumah menempel dengan pondasi teras rumah bagian samping.

\section{Jembatan Kali-Anyar (Kali-Baru)}

Kali-Baru merupakan kanal sodetan Kali-Sukalila yang dibuat untuk menyalurkan air dari hulu ke laut, sehingga kali ini berubah nama menjadi Kali Baru dari mulai Kali Sukalila sampai ke laut. Jembatan Kali Baru berlokasi di Kali-Baru atau Kali-Anyar di Jalan Sisingamangaraja dekat pelabuhan, tepatnya tidak jauh dari pintu III pelabuhan pada koordinat $108^{\circ} 33^{\prime} 56,211^{\prime \prime} \mathrm{E} ; 6^{\circ} 42^{\prime} 40,557^{\prime \prime} \mathrm{S}$. Jembatan ini posisinya berdampingan dengan jembatan jalan raya. Pada gambar 8 , foto yang berterakan tahun 1910, jembatan kereta api dan jembatan jalan raya sejajar dengan posisi rel 
kereta api yang sejajar dengan permukaan jalan raya. Konstruksi jembatan adalah besi dengan penguat paku keling, memiliki bagian diagonal pada kedua sisinya. Secara rinci ukuran jembatan tersebut, lebar $4 \mathrm{~m}$, panjang 24,80 m dan tinggi bagian sisi (diagonal) $3 \mathrm{~m}$ dengan posisi rel berada di tengah jembatan. Pada saat ini, posisi jembatan kereta api lebih rendah dibanding jembatan jalan raya. Penambahan tinggi jalan raya dibanding lingkungan sekitar, termasuk rel kereta api, terjadi karena dilakukannya peninggian muka jalan secara rutin dari waktu ke waktu. Rel kereta api yang dipasang di jembatan sudah tidak ada, tersisa bekas dudukan atau pengikat bantalan rel (gambar 8).

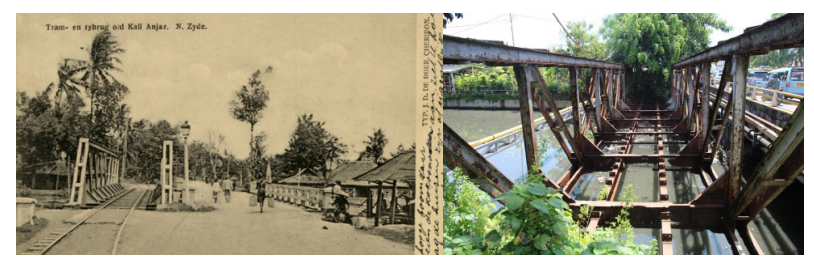

Gambar 8. Jembatan Kalianyar/Kaibaru: (kiri) Tahun 1910

(sumber: https://digitalcollections. universiteitleiden.nl) dan (kanan) Tahun 2019.

(Sumber: Dokumentasi Balar Jawa Barat, 2019)

\section{Lingkungan Pelabuhan}

\section{Stasiun Cirebon Pelabuhan}

Stasiun Cirebon Pelabuhan $(\mathrm{CNH})$, merupakan stasiun yang dibangun oleh Perusahaan Kereta Api Swasta, NV. SCS di lingkungan pelabuhan guna menampung komoditas yang diangkut oleh perusahaan trem tersebut, yang akan dikapalkan ekspor, dan komoditas impor yang akan dikirim ke pedalaman. Menurut Raap (2017, 243), Stasiun Cirebon Pelabuhan merupakan stasiun pertama yang dibangun SCS pada tahun 1897 sebagai stasiun akhir, pendapat Raap tersebut berbeda dengan Oogema $(1982,156)$, yang menyatakan stasiun Cirebon Pelabuhan baru dibangun dan dioperasikan tahun 1899. Berdasarkan Arsip Kolonial Hindia Belanda, yaitu besluit van Gouverneur Generaal Nomor 53 tanggal 26 Juli 1899 , yang isinya tentang adanya peraturan baru pembangunan jalan trem ke Cirebon, salah satu ketentuannya adalah, "Bila dalam persyaratan ini disebutkan tentang jalan trem dari Semarang ke Cirebon, juga di dalamnya termasuk cabang-cabang ke pelabuhan yang terletak di sepanjang jalur ini, maka dalam keputusan khusus ijin diberikan oleh Gubernur Jenderal untuk membuka dan mengeksploitasinya". Aturan ini muncul karena walau sejak awal pihak SCS mengajukan permohonan untuk dapat membangun jaringan rel ke pelabuhan, namun pemerintah belum mengabulkannya. Alasannya, lahan dan manajemen pelabuhan belum siap menerima kontak jaringan rel dan transportasi darat dengan pihak perusahaan NV. SCS. Guna mengatasi kemacetan tersebut, NV. SCS dan manajemen pelabuhan mengadakan pembicaraan dengan pemerintah, dan hasilnya adalah ketentuan yang dimuat dalam Besluit van Gouverneur tanggal 26 Juli 1899 Nomor 53. Berdasarkan aturan tersebut, maka SCS mulai membangun rel trem ke pelabuhan Cirebon (Marihandono et al. 2016, 91).

Uraian tersebut menunjukkan, bahwa Stasiun atau Halte Cirebon Pelabuhan dibangun dan dioperasikan SCS, setelah terbitnya aturan baru di tanggal 26 Juli 1899. Sebelum diizinkan untuk membangun fasilitas perkeretaapian di Pelabuhan Cirebon, Stasiun Cirebon SCS atau Stasiun Cirebon Prujakan merupakan tempat berakhirnya perjalanan kereta api dari Semarang ke Cirebon. Komoditas yang diangkut kereta api diturunkan di Gudanggudang komoditas Stasiun Cirebon Prujakan dan selanjutnya diangkut dengan menggunakan gerobak dari Stasiun Cirebon Prujakan ke Pelabuhan Cirebon.

Berdasarkan Grondkart milik PT. Kereta Api Indonesia (gambar 9), emplasemen Stasiun Cirebon Pelabuhan memiliki lima sepur dan dua sepur Badug. Pada gambar tersebut juga terdapat jalur tunggal yang mengarah ke Timur. Jalur tersebut merupakan jalur ke dermaga pelabuhan, gudang pelabuhan dan menuju pergudangan di sekitar Jalan Cangkol (sekarang Jalan Sisingamangaraja). Jalur rel tersebut berakhir di gudang milik KPM (Koninklijke 


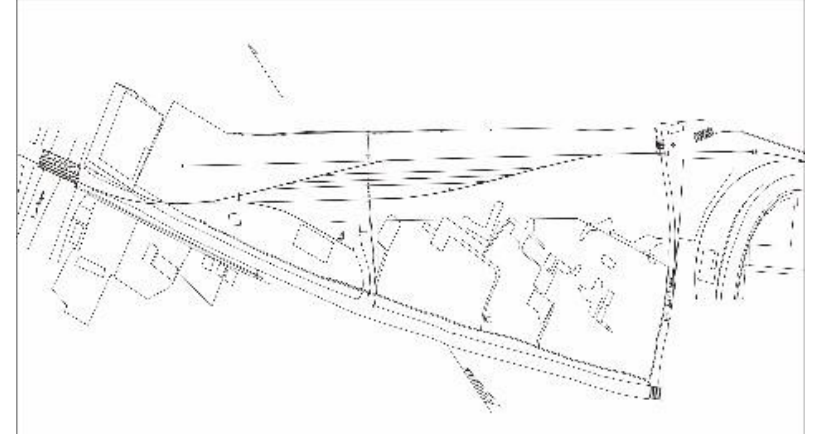

Gambar 9. Denah Emplasemen Pelabuhan berdasarkan Grondkart No. 3.

(Sumber: Grondkart PT. KAI Daop 3 CN, disalin dengan Izin)

Paketvaart-Maatschappij), sekarang menjadi aset Bank Mandiri.

Hasil survei lapangan menunjukkan, Stasiun Kereta Api Cirebon Pelabuhan (CNH) berada di Jalan Sisingamangaraja, di sisi Utara Rumah Sakit Pelabuhan Cirebon pada koordinat 6 42’ 45,410”'LS; $108^{\circ} 34^{\prime} 1,590^{\prime}$ 'BT. Semenjak kereta api tidak meyalani jalur ke Pelabuhan Cirebon, Stasiun Cirebon Pelabuhan dibiarkan tidak terawat, dan kondisi saat ini menunjukkan bangunan Stasiun Cirebon Pelabuhan sudah tidak ada, serta tidak ditemukan jejak rel atau tinggalan lainnya yang menunjukkan sebagai bekas emplasemen stasiun. Lahan bekas emplasemen stasiun Cirebon Pelabuhan tersebut difungsikan sebagai: (1) Lahan tempat parkir truk di lingkungan Pelabuhan Cirebon; (2) Bagian dari Rumah Sakit Pelabuhan; dan (3) Sebagai lahan kosong yang difungsikan sebagai tempat penimbunan barang bekas.

Akibat lahan bekas emplasemen Stasiun Cirebon Pelabuhan $(\mathrm{CNH})$ sudah beralih fungsi, ketika survei lapangan dilakukan tidak ditemukan jejak atau tinggalan fasilitas perkeretaapian. Menurut informasi yang diperoleh dari Ibu Yuli, umur 41 tahun (Staf Rumah Sakit Pelabuhan Cirebon), berdasarkan informasi yang diperolehnya, dan sepengetahuan beliau bahwa di bagian belakang Rumah Sakit Pelabuhan, dahulunya masih bisa dijumpai rel-rel kereta api, tetapi sekarang sudah tidak ada karena di atasnya sudah dibangun Fasilitas Pulasara Jenazah dan tempat genset rumah sakit.

Berdasar uraian tersebut, bukti-bukti keberadaanjalurkereta apikePelabuhan Cirebon berupa tinggalan fasilitas perkeretaapian dan keberadaan kawasan komplek pergudangan di pelabuhan dan sekitarnya menunjukkan, bahwa jalur kereta api dari Stasiun Cirebon - Stasiun Cirebon Pelabuhan, merupakan jalur penting bagi angkutan komoditas ekspor impor pada masa Kolonial Belanda melalui Pelabuhan Cirebon. Keberadaan dermaga yang dapat disinggahi kapal-kapal lintas samudera, dan fasilitas penyimpanan sementara berupa gudang-gudang yang dibangun di lingkungan pelabuhan dan sekitarnya, menunjukkan Pelabuhan Cirebon merupakan salah satu pelabuhan yang penting bagi perdagangan pada masa itu. Moda angkutan kereta api yang mengangkut berbagai komoditas dari, dan ke pedalaman Pulau Jawa menjadi sarana penghubung antara pedalaman dengan pesisir.

\section{KESIMPULAN}

Pembangunan perkeretaapian pada masa Kolonial Belanda tidak terlepas dari kepentingan ekonomi. Meningkatnya permintaan akan komoditas gula dari pasaran dunia menjadi salah satu alasan dibangunnya jaringan kereta api di Pulau Jawa, termasuk pembangunan jalur kereta api ke Pelabuhan Cirebon. Hubungan antara daerah penghasil di wilayah pedalaman dengan Pelabuhan-pelabuhan utama di Pulau Jawa, termasuk Pelabuhan Cirebon, terus ditingkatkan guna memperlancar pengangkutan komoditas-komoditas tersebut. Penguatan aktivitas pengangkutan barang dan jasa dilakukan melalui konsep kerja sama yang saling menguntungkan antara SCS dengan SS, yaitu melalui pengalihan pengangkutan dari kereta SCS ke SS atau sebaliknya. Peralihan pengangkutan barang dilakukan di stasiun yang bersinggungan, barang atau komoditas yang diangkut oleh gerbong SCS untuk tujuan daerah konsesi SS, akan dipindah pengangkutannya ke 
gerbong SS demikian pula sebaliknya, barang atau komoditas tujuan daerah konsesi SCS yang diangkut kereta SS, akan dipindah ke gerbong SCS, termasuk tujuan pelabuhan. Tinggalan perkeretaapian di jalur non-aktif Stasiun Cirebon - Pelabuhan Cirebon, yaitu singkapan rel, tiang persinyalan, jembatan, patok batas, dan patok KM, merupakan bukti keberadaan angkutan kereta api yang menghubungkan Stasiun Cirebon dengan kawasan Pelabuhan Cirebon. Hal ini juga menjadi bukti peran penting kereta api sebagai moda angkutan komoditas industri perkebunan dan komoditas lainnya di wilayah Cirebon pada masa Kolonial Belanda.

\section{UCAPAN TERIMA KASIH}

Penyusun mengucapkan terima kasih kepada semua anggota Tim Penelitian Arkeologi tentang Perkeretaapian di Cirebon tahun 2017, 2018, dan 2019; kepada VP PT. KAI DAOP 3 Cirebon, khususnya Manajer Aset beserta staf yang telah membantu selama kegiatan penelitian lapangan; kepada Kepala Bidang Kebudayaan di kabupaten Majalengka, Kabupaten Cirebon, dan Kota Cirebon beserta staf yang telah membantu kelancaran penelitian, serta kepada rekan-rekan di IRPS Bandung - Cirebon, Kereta Anak Bangsa, serta pihak-pihak lainnya yang telah membantu dan mendukung kelancaran penelitian ini.

\section{DAFTAR PUSTAKA}

Arsip Nasional Republik Indonesia. 1976. Memori Serah Jabatan 1921-1930 (Jawa Barat) 1. Jakarta: Arsip Nasional Indonesia.

Cahyo, Dedi Nur. 2017. "Perkembangan Transportasi Kereta Api di Kabupaten Lamongan Tahun 1899 - 1932." Avatara 5 (1): 1402-16. https://jurnalmahasiswa.unesa. ac.id/index.php/avatara/article/view/17733.

Darini, Ririn, Muji Hartono, Miftahuddin, Eko Ashari, dan Yoga Budhi Sulistyo. 2014. "Laporan Penelitian: Kereta Api di Jawa tengah dan Yogyakarta Tahun 1864-1930." Yogyakarta.
Hendro, Eko Punto. 2014. "Perkembangan Morfologi Kota Cirebon Dari Masa kerajaan Hingga Akhir Masa Kolonial.” Paramita: Historical Studies Journal 24 (1): 17$30 . \quad$ https://doi.org/10.15294/paramita. v24i1.2861.

Hermawan, Iwan, dan Revi Mainaki. 2019. "Pemetaan Jalur dan Tinggalan Perkeretaapian Masa Kolonial Belanda di Wilayah cirebon Timur." Sosioteknologi 18 (3): 560-77. https://doi.org/http://dx.doi. org/10.5614\%2Fsostek.itbj.2019.18.3.21.

Lubis, Nina H. 2000. "Cirebon.” In Sejarah Kotakota Lama di Jawa Barat, diedit oleh Nina H. Lubis, 21-48. Bandung: Alqaprint.

Marihandono, Djoko. 2016. "Pembangunan Jalur Kereta Api Dan Trem Di Cirebon.” Diakronik 1 (1): 5-23. http://jurnal.fib.uns.ac.id/index. $\mathrm{php} /$ diakronik/article/view/58.

Marihandono, Djoko, Harto Juwono, Langgeng Sulistyo Budi, dan Dyah Iswari. 2016. Sejarah Kereta Api Cirebon - Semarang, Dari Konsesi ke Nasionalisasi. Diedit oleh Endro Yulianto. Bandung: Aset Non Railway, Direktorat Aset Tanah dan Bangunan PT. Kereta Api Indonesia (Persero).

Oegema, JJG. 1982. De Stoomtractie Op Java en Sumatra. Netherlands: Kluwer Technische Boeken.

Raap, Olivier Johannes. 2017. Sepoer Oeap Djawa Tempo Doeloe. Jakarta: Kepustakaan Populer Gramedia. "Regeerings-Almanak Voor Nederlandsch-Indie 1930. Eerste Gededeelte ."1930. Weltevreden - Batavia.

Reiter, Bernd. 2017. "Theory and Methodology of Exploratory Social Science Research |." IJRM: International journal of science and research methodology. 5 (4): 129-50. http://ijsrm.humanjournals.com/theory-andmethodology-of-exploratory-social-scienceresearch/.

Subarkah, Imam. 1992. 125 Tahun Kereta Api Kita, 1867-1992. Bandung: Yayasan Pusaka.

Sumaatmadja, Nursid. 1988. Studi Geografi: Suatu pendekatan dan Analisa Keruangan. II. Bandung: Alumni.

Tim Telaga Bakti Nusantara. 1997. Sejarah Perkeretaapian Indonesia Jilid 1. Bandung: Angkasa. 
Usman, dan Rachmatsyah. 2017. "Kereta Api sebagai Sarana Transportasi Militer Kolonial Belanda dalam Perang Aceh (Suatu Kajian Historis dan Ekonomi di Pantai Timur Aceh Tahun 1900-1942)." In Prosiding Seminar Nasional Tahunan Fakultas Ilmu Sosial Universitas Negeri Medan Tahun, 1:587-98. Medan: Fakultas Ilmu Sosial Universitas Negeri Medan. http://semnastafis.unimed. ac.id.
Wardhani, Fifi Lutfia. 2014. "Kajian Kelas Sosial Pada Rumah Pegawai Stasiun kereta Api Kedjaksan Cirebon 1911-1942." PURBAWIDYA: Jurnal penelitian dan Pengembangan Arkeologi 3 (2): 141-56. https://doi.org/10.24164/pw.v3i2.42. 